ISSN 1816-6075 (Print), 1818-0523 (Online)

Journal of System and Management Sciences

Vol. 11 (2021) No. 1, pp. 38-53

DOI:10.33168/JSMS.2021.0103

\title{
On-the-job Consumption, Internal Control Quality, and Corporate Performance
}

\author{
Yiwei Wang ${ }^{1}$ and Shanyue $\mathrm{Jin}^{2 *}$ \\ ${ }^{1}$ Department of Global Business, Gachon University, Korea \\ ${ }^{2}$ Corresponding Author, Department of Global Business, Gachon University, Korea \\ ${ }^{1}$ pdswyzhe@gmail.com,2*jsyrena0923@gachon.ac.kr
}

\begin{abstract}
The phenomenon of on-the-job consumption by management generally occurs during company operations, and has become a hidden means of corruption by management. This study collected data on non-financial companies listed on the Main Boards of the Shanghai and Shenzhen stock exchanges from 2009 to 2018. By analyzing the relationship between internal controls, on-the-job consumption, and corporate performance, this study examines whether internal controls can mitigate the impact of such consumption on company performance. Through quantitative analysis, the study finds that in-service consumption has a negative relationship with company performance, and that internal controls play a large moderating role between on-the-job consumption and corporate performance. The study also provides theoretical and empirical evidence to advocate for internal control regulations and related policies that better prevent and supervise the on-thejob consumption behavior of listed company executives..
\end{abstract}

Keywords: On-the-job consumption, internal control, corporate performance, executive rent-seeking, moderating effect. 


\section{Introduction}

Jensen and Meckling (1976) found that managers were likely to undertake rentseeking behavior, and that a lack of supervision increased management's nonmonetary benefits.

Wan (2007) argued that on-the-job consumption refers to any remuneration or special treatment of corporate executives, in addition to their salaries. These included luxury offices, private cars, and the use of corporate funds for entertainment and catering. The normal in-service consumption incurred by senior corporate executives while performing their duties is a consumption expenditure that the enterprise should bear and is reasonable in itself. In reality, however, some executives seek personal privileges for food, clothing, housing, transportation, and enjoy luxury consumption in the name of in-service consumption, which damages the corporation's image. Onthe-job consumption is a form of hidden corruption that easily leads to vast losses for an enterprise (Liang, 2007).

The on-the-job consumption problem occurs in many countries. Due to China's particular institutional background and lack of supervision, it cannot effectively curb its problem with public funds consumption, meaning that executives employ their powers to occupy public assets.

This study divided in-service into two views: agency and efficiency. Berle and Means (1932) suggested that if shareholders were too scattered to supervise management effectively, senior executives were likely to take advantage of company assets for private gain, including as additional allowances and subsidies. Job consumption is a personal benefit, in which the cost exceeds the efficiency gain and will reduce corporate performance. Thus, it is an agency cost and has a negative effect on corporate performance.

On the other hand, the efficiency view states that although on-the-job consumption has become a means for executives to engage in rent-seeking, the universality of its existence cannot be fully explained by the "agency view." Therefore, in-service consumption has become a means for senior management to seek rents, and the widespread nature of its existence cannot be fully explained by the "agency view." In terms of maintaining business relationships, executives' on-the-job consumption may also bring benefits to enterprises (Rajan and Wulf, 2004).

The agency view appears to contradict the efficiency view, but it has a certain logical consistency. On-the-job consumption will still exist even if there is no separation of the principal and agent. In that case, the decisions made by the manager (that is, the owner) would accord with the principle of efficiency. Therefore, on-thejob consumption reflects an efficiency effect under an effective supervision system. Separating the two powers usually serves the purpose of maximizing shareholders' wealth by providing on-the-job consumption to senior executives. If there is no supervision system, executives will pursue their own self-interests through in-service consumption, which occupies the company's resources and thus reduces the 
corporation's value.

According to the principal-agent theory, the principal is the company's investor and the agent is the company's management. Job consumption is a type of position appreciation other than salary that the management can easily realize by exercising power. To better protect the interests of the consumer, strengthening the supervision of management is an inevitable measure, or adopting more attractive incentives to make the management and the client form a community of destiny and value. Hence, as an effective internal supervision measure, internal control plays an important role in corporate governance. When strengthening the construction of internal control and the internal supervision information disclosure system, executives consciously regulate their management behaviors, thereby reducing agency costs and on-the-job consumption. The main goal of internal control is to ensure the legality and compliance of business management activities, asset safety, and reliability of financial report information. The sound internal control system is an important symbol of high-quality company operations.

Developed countries have sound corporate governance systems, and the problem of on-the-job consumption is therefore not a particularly prominent issue. Due to the imperfect internal supervision systems of Chinese enterprises, some executives of listed companies include such consumption as an implicit compensation contract, which becomes a hidden form of corruption (Xu and Liu., 2013).

Internal control includes five aspects: control environment, risk assessment, control activities, information sharing, and internal supervision. Among them, the control environment requires companies to establish a board of directors, a general meeting of shareholders, and a board of supervisors in accordance with the law, and regulates the deliberations of the three meetings. They are the top-level devices for the overall operation of internal control. A good internal control environment is a prerequisite for the effective implementation of such control (Lee, 2020). The implementation of the risk assessment and formulation of the corresponding countermeasures are the basis for the implementation of internal control. Only by scientifically assessing the risks that may occur can we accurately implement supervision and improve the effectiveness of regulation. Control activities require enterprises to formulate executive management rules, which is the key to operation of internal control. Information communication encourages listed companies to establish effective internal and external communication methods to alleviate information asymmetry. Internal supervision encourages companies to find and repair defects in daily operations and investment in time. Therefore, sound internal control can affect senior executives' job consumption behavior from many aspects.

Li et al. (2012) empirically tested the relationship between in-service consumption and performance of Chinese companies and found that in-service consumption by the management had a negative impact on their business performance. Ma and Ye (2016) found that in China, in-service consumption by management significantly reduced 
their company's performance.

From the perspective of corporate governance, the impact of in-service consumption on company performance is caused by the company's imperfect internal governance mechanism (Shim and Jung, 2020). Effective internal control is a secret many well-known enterprises employ to achieve long-term stability. According to China's regulations, the board of directors exercises management decision-making power, while the board of supervisors oversees management executives such as directors and managers. If internal control is implemented effectively, then it supervises the power of senior management effectively. Mou et al. (2016) empirically determined that high-quality internal controls significantly reduced in-service consumption at listed companies, especially state-owned companies. Good internal corporate governance (high-quality internal control) can effectively supervise the behavior of senior executives, thus reducing internal agency costs. It ensures that the company focuses on its main business, and its major investment decisions can be implemented effectively, increasing company performance. On the contrary, a company with disordered internal governance will eventually reflect company performance and reduce corporate performance.

On-the-job consumption is a difficult problem in terms of Chinese corporate governance. During daily business activities, executives inevitably incur expenses such as travel and business entertainment and on-the-job consumption is inevitable. However, it is difficult to monitor and control such consumption effectively because it is difficult to determine which expenditures are abnormal. This study examines whether internal controls affect the in-service consumption behavior of self-interested executives, and whether internal controls restrict senior executives' on-the-job consumption, helping companies restrain executives from implementing inefficient in-service consumption.

This study takes internal control as a constraint and establishes an econometric model of internal control for in-service consumption constraints. It then measures corporate performance along two dimensions, total return on assets (ROA) and total return on equity (ROE), to determine the impact of internal controls on company performance by utilizing in-service consumption.

The contribution of this study lies in its empirical examination of the effectiveness of internal control systems within Chinese enterprises. This provides a theoretical basis for employing internal controls to suppress senior executives' on-the-job consumption and thus improve enterprise performance. It also provides effective policy recommendations for Chinese firms that wish to improve their internal control systems and supervise the in-service consumption of their senior executives. 


\section{Theoretical background}

\subsection{Principal-agent theory}

Berle and Means (1932) utilized an economic perspective to analyze the interest friction between principals and agents after the separation of ownership and management rights in an enterprise.

Principal-agent theory states that one or more principals entrust an agent to complete certain actions on their behalf via a contract, which establishes a principalagent relationship between the two parties with the purpose of maximizing their interests. Because the agent and the principal have different interests, the principal is at an informational disadvantage, and if it cannot fully supervise the agent, the agent will act for their own benefit. This is detrimental to the principal's interests, which creates an agency problem.

Executive job consumption is one of the typical performance of agency problems. Because there has not yet been a comprehensive reputation-oriented market for professional managers, reputation has become insignificant for managers compared to realizing short-term profit maximization. Managers will use on-the-job consumption to increase their short-term private income. In-service consumption will bring higher agency costs to the company and will have a negative impact on the total value of the company.

During the operation of a company, managers have informational advantages, motivation, and the ability to occupy company resources, and on-the-job consumption is one such method. Xu and Yan (2011) argued that the principal-agent relationship chain was complicated in Chinese state-owned enterprises, internal governance efficiency was low, and it was more likely to occur as in-service consumption by executives.

\subsection{Signalling theory}

Signal display is a mechanism that allows the party at a disadvantage to obtain undisclosed private information. The signal display is aimed at the side who owns private information and establishes an information mechanism to protect the principal's trading rights. Under this mechanism, both parties to the transaction reach an agreement that the agent who has more private information should accurately disclose it to the principal. Signaling theory is therefore an effective means to solve the problem of information asymmetry. Information can guide price setting, reflect the effectiveness of economic markets and allocation efficiency of resources, and plays an indispensable core role. The existence of any information must theoretically induce the signal display. The party who has the advantage of information will actively and voluntarily disclose it and convey it to the other party. Therefore, information disclosure has become an important way for contractual parties to communicate information. 


\subsection{Incomplete contract theory}

Based on principal-agent theory (complete contract theory), Grossman and Hart (1986) proposed an incomplete contract theory. Their theory states that, due to individual bounded rationality, imperfect information, and the uncertainty of transaction matters, the proposed contract cannot cover all of the agent's responsibilities and rights under various uncertain conditions. Incomplete contracts are inevitable and common. Therefore, the client should pay attention to avoiding the problems of inadequate consideration and post-supervision caused by incomplete contracts. To reduce contract incompleteness, Hart (1995) proposed that methods of control during events must be established, and principals must rely more on the power of internal rather than external supervision. The company's internal control system can regulate the agents.

If agents believe that their rights and feelings are satisfied, they will perform their duties according to the contract. However, if they believe that their rights have been infringed, they will act speculatively (Hart and Moore, 2008). Executives will increase their non-monetary benefits through other means to maximize their utility precisely because contracts between shareholders and executives are incomplete.

\section{Research hypothesis}

In-service consumption behavior is common in companies. The primary reason is the separation between ownership and control, which results in "owner vanity," and because companies lack an effective supervision mechanism, which leads to agency problems. Power is concentrated in the hands of managers, who can use it for on-thejob consumption and personal benefits (Xie and Lu, 2019).

In-service consumption is a common agency cost that is certainly reasonable (Luo and Huang, 2008). Li,Qin and Huang(2010) found that on-the-job consumption had a particular incentive effect in state-owned enterprises. More scholars argue that such consumption is a means for executives to occupy corporate resources and a way to trigger agency conflicts, which will reduce the level of corporate governance and the value of the enterprises.

In summary, on-the-job consumption is a method by which executives use their power to encroach on the interests of the enterprise and pursue their private interests. An increase in such consumption levels definitely reduces the value of the enterprise and damages the interests of shareholders. This study measures corporate performance along two dimensions to determine the relationship between in-service consumption and corporate performance. We therefore formulate the following hypotheses:

H1-a: A company's in-service consumption level negatively correlates with its ROA.

H1-b: A company's in-service consumption level negatively correlates with its ROE. 
A contract theory is formed on the basis of the separation of enterprise ownership and management rights, but it is unrealistic to make a complete contract. The problem of incomplete contracts is widespread in the company's management process. To solve this problem, as a common means of corporate governance, internal control can be used to solve the incomplete contract problem.

Internal control is essentially a system of an enterprise, which is a series of control activities implemented by various levels of the corporation to ensure the realization of organizational goals and to control the enterprise's risk within a reasonable range. The quality of internal control may effectively improve the quality of accounting information. Not only can the five elements of internal control (internal control evaluation system) make corporate financial reports more authentic and reliable, but also from the five goals of strategy, safety, operation, reporting, and compliance (based on relevant systems and methods) to prevent managers from using accounting policies to manipulate profits.

Chen (2016) suggested that firms with high internal control quality decreased the agency costs caused by information asymmetry and reduced self-interested executive behavior. Therefore, internal control is important in corporate governance. Effective internal control helps limit the power of management and reduces senior executives' rent-seeking behavior (Zhang and Xiu, 2017).

Improving corporate internal control quality can mitigate the effect of on-the-job consumption on the company's operating performance. We measure corporate operating performance along two dimensions and examine the moderating role of internal control in the relationship between in-service consumption and performance. We therefore formulate the following hypotheses:

$\mathrm{H} 2-\mathrm{a}$ : In-service consumption in listed companies with higher internal control quality has less impact on their ROA.

H2-b: In-service consumption in listed companies with higher internal control quality has less impact on their ROE.

\section{Research methodology}

\subsection{Sample selection and source of data}

The research sample includes all Chinese listed companies from 2009 to 2018, a total of 10 years. It does not include financial companies, GEM(Growth Enterprises Market), or samples with missing data, resulting in a sample of 17,824 companies. All data were obtained from CSMAR, except for the on-the-job consumption data, which were manually collected from company annual reports. We utilized SAS 9.4 for the empirical analysis and winsorized all continuous variables at the $1 \%$ level to eliminate the influence of outliers. 


\subsection{Variable definition}

Dependent variables: This study selected two accounting indicators, ROA and ROE, as proxy variables for corporate performance.

Independent variables: Since there is no specific disclosure regarding on-the-job consumption in company annual reports, previous research has generally adopted adjusted management costs as a proxy. This study adopts Chen and Wan's (2005) method. We collected the data by referring to the "Cash Flows Paid in relation to Other Operating Activities" item in the notes of the annual reports of companies listed on the Shanghai and Shenzhen exchanges. The regulation rules of this project stipulated that senior executives' on-the-job consumption was generally included in management costs. It is easier for executives to utilize management expense items for their own self-interest, so it is reasonable to obtain data on in-service consumption from management costs. This study employed eight item costs, including office, travel, business entertainment, and communication expenses, and overseas training, boarding, trolley, and conference fees, as proxy variables for on-the-job consumption by executives.

Moderator variables: Following $\mathrm{Hu}$ and Gan (2015), the Shenzhen Dibo Internal Control Information Disclosure Index is utilized as a proxy for the internal control quality of a company. The index employs a thousand-point system, with scores ranging from 0 to 1000 . Higher scores indicate better quality of the company's internal controls.

Control variables: To control for the unique characteristics of each enterprise and its executives, this study follows Beneish (2008) in selecting company size, financial leverage, board size, the combination of director and general manager, and executive compensation as control variables, adding two dummy variables for industry and year. Definitions of each variable are presented in Table 1. 
Table 1: Variable definitions

\begin{tabular}{|c|c|c|c|}
\hline $\begin{array}{l}\text { Variable } \\
\text { type }\end{array}$ & $\begin{array}{l}\text { Variable } \\
\text { name }\end{array}$ & $\begin{array}{l}\text { Variable } \\
\text { code }\end{array}$ & Calculation method \\
\hline \multirow{2}{*}{$\begin{array}{l}\text { Dependent } \\
\text { variable }\end{array}$} & \multirow{2}{*}{$\begin{array}{l}\text { Corporate } \\
\text { performance }\end{array}$} & ROA & Net profit/total assets \\
\hline & & ROE & Net profit/net assets \\
\hline $\begin{array}{l}\text { Independe } \\
\text { nt variable }\end{array}$ & $\begin{array}{l}\text { On-the-job } \\
\text { consumption }\end{array}$ & Perks & $\begin{array}{l}\text { Logarithm of the sum of eight } \\
\text { management expenses }\end{array}$ \\
\hline $\begin{array}{l}\text { Moderator } \\
\text { variable }\end{array}$ & $\begin{array}{l}\text { Internal } \\
\text { control quality }\end{array}$ & LnIC & $\begin{array}{l}\text { Dibo's internal control index (logarithm } \\
\text { of a value between } 0 \text { and 1000) }\end{array}$ \\
\hline \multirow{7}{*}{$\begin{array}{l}\text { Control } \\
\text { variable }\end{array}$} & Company Size & Size & Natural $\log$ of total assets \\
\hline & $\begin{array}{l}\text { Financial } \\
\text { leverage }\end{array}$ & Lev & $\begin{array}{l}\text { Asset-liability ratio = total } \\
\text { liabilities / total assets }\end{array}$ \\
\hline & Board size & Board & Board of Directors \\
\hline & CEO duality & Power & $\begin{array}{l}\text { Whether the chairman and the CEO are } \\
\text { concurrent, } 1 \text { if they are, otherwise } 0\end{array}$ \\
\hline & $\begin{array}{l}\text { Executive } \\
\text { compensation }\end{array}$ & Wage & Total salary of top 3 executives $/ 10,000$ \\
\hline & Industry & INDUS & Dummy variable \\
\hline & Years & Year & Dummy variable \\
\hline
\end{tabular}

To investigate the impact of on-the-job consumption on enterprise performance, we utilized the following regression models to test the regulatory effect of internal controls, and our hypotheses (Jeong and Choi, 2020).

Models (1) and (2) studied the relationship between on-the-job consumption, ROA, and ROE. The models controlled for factors such as company size, financial leverage, board size, Chairman-CEO duality, and executive compensation, and verified that executive on-the-job consumption had a negative correlation with corporate performance. If $\beta 1>0$, there was a positive correlation between in-service consumption and corporate performance. If $\beta 1<0$, it indicated a negative correlation between in-service consumption and corporate performance.

$$
\begin{gathered}
\text { ROA }=\beta_{0}+\beta_{1} \text { Perks }+\beta_{2} \text { Size }+\beta_{3} \text { Lev }+\beta_{4} \text { Board }+\beta_{5} \text { Power }+\beta_{6} \text { Wage }+ \\
\sum I N D U S+\sum \text { Year }+\varepsilon \\
\text { ROE }=\beta_{0}+\beta_{1} \text { Perks }+\beta_{2} \text { Size }+\beta_{3} \text { Lev }+\beta_{4} \text { Board }+\beta_{5} \text { Power }+\beta_{6} \text { Wage }+ \\
\sum I N D U S+\sum \text { Year }+\varepsilon
\end{gathered}
$$

Models (3) and (4) added internal controls to Models (1) and (2) as a moderating variable, examined the role of internal controls in the relationship between executive consumption and performance, and verified whether higher-quality internal controls reduced the influence of in-service consumption on enterprise performance.

$$
\begin{gathered}
\text { ROA }=\beta_{0}+\beta_{1} \text { Perks }+\beta_{2} \text { LnIC }+\beta_{3} \text { Perks } * \text { LnIC }+\beta_{4} \text { Size }+\beta_{5} \text { Lev }+ \\
\beta_{6} \text { Board }+\beta_{7} \text { Power }+\beta_{8} \text { Wage }+\sum \text { INDUS }+\sum \text { Year }+\varepsilon
\end{gathered}
$$


$R O E=\beta_{0}+\beta_{1}$ Perks $+\beta_{2}$ LnIC $+\beta_{3}$ Perks $*$ LnIC $+\beta_{4}$ Size $+\beta_{5}$ Lev + $\beta_{6}$ Board $+\beta_{7}$ Power $+\beta_{8}$ Wage $+\sum$ INDUS $+\sum$ Year $+\varepsilon$

\section{Empirical results and analysis}

\subsection{Descriptive statistics}

According to Table 2, the total number of companies in the sample was 17,824 .

Table 2. Descriptive variable statistics

\begin{tabular}{|c|c|c|c|c|c|c|}
\hline Variable & $\mathbf{N}$ & Mean & $\begin{array}{c}\text { Standard } \\
\text { deviation }\end{array}$ & Median & Min & Max \\
\hline ROA & 17,824 & 0.037 & 0.118 & 0.033 & -0.707 & 0.707 \\
\hline ROE & 17,824 & 0.060 & 0.152 & 0.064 & -0.754 & 0.653 \\
\hline Perks & 17,824 & 16.057 & 1.265 & 16.035 & 8.470 & 21.924 \\
\hline LnIC & 17,824 & 6.150 & 1.431 & 6.503 & 0.000 & 6.886 \\
\hline Size & 17,824 & 22.050 & 1.267 & 21.925 & 13.763 & 27.591 \\
\hline Lev & 17,824 & 0.442 & 0.218 & 0.433 & 0.051 & 0.973 \\
\hline Board & 17,824 & 8.634 & 1.725 & 9.000 & 3.000 & 18.000 \\
\hline Wage & 17,824 & 193.042 & 191.794 & 146.475 & 25.010 & 4381.000 \\
\hline Power & 17,824 & 0.254 & 0.436 & 0.000 & 0.000 & 1.000 \\
\hline
\end{tabular}

The mean of the two indicators ROA and ROE, which measure corporate performance, are 0.037 and 0.060 , respectively. Overall, Chinese companies have good operating conditions. However, the extreme value of performance indicators varies greatly, indicating that the operating profitability of Chinese listed companies also varies significantly.

The mean on-the-job consumption was 16.057 , with a minimum of 8.470 and a maximum of 21.924. This shows that there is a great difference in on-the-job consumption of Chinese listed companies.

The minimum value of the internal control index is 0 , the maximum value is 6.886 , and the average value is 6.150 , indicating that the internal control quality of Chinese listed companies is generally good, but the average and median of internal control are relatively close, indicating that the internal control quality of half of enterprises is lower than the average level. Moreover, the internal control index of some enterprises is 0 , indicating that these enterprises have major defects in their internal control systems, so the execution and effectiveness of internal control regulations should be improved.

The average size of the company is 22.050 , and the standard deviation is large, revealing that there is a large gap in the asset size of each company.

The average of companies' asset-liability ratio is $44.1 \%$, showing that their capital structure is at a reasonable level. With a minimum value of 0.051 and a maximum value of 0.973 , some companies' liabilities are only about $5 \%$ of their total assets, while some companies' debt ratios are up to $97.3 \%$, meaning that assets are almost 
entirely obtained from liabilities and hence, the financial risk is very high. These companies should reduce corporate debt to increase corporate value and create corporate benefits.

The average size of the board of directors was 8.634. According to the provisions of China's "Corporation Law," the number of board of directors of listed companies is reasonable.

The average value of CEO duality was 0.254 . The chairman of the board also serving as the general manager is not common in Chinese listed companies, accounting for about $25 \%$. Most companies have separated the roles of chairman and general managers, which helps the board of directors to strengthen their ability to supervise and balance senior executives.

\subsection{Correlation analysis of variables}

Table 3 shows the Pearson correlation coefficients between variables. The results show that Perks had a significant negative correlation with ROA, indicating that the more on-the-job consumption, the lower the corporate performance, which provides initial support for the hypothesis-1; The internal control and ROA are positively correlated at the $1 \%$ level, indicating that the higher the quality of corporate internal control, the better corporate performance. In addition, The highest correlation coefficient among the other variables was 0.62 , indicating there was no serious multicollinearity among them.

\subsection{Regression analysis}

Table 4 presents the regression analysis results for Models (1) to (4).

The column for Model (1) reveals the regression results for in-service consumption and ROA, finding a negative correlation at the 5\% level, which is consistent with hypothesis H1-a. As agency theory states, as the level of executive in-service consumption increases, the company's ROA decreases. The column for Model (2) examines the relationship between in-service consumption and ROE. The regression coefficient was negatively correlated at the 5\% level, supporting hypotheses H1-b, and the level of significance was consistent with Model (1), indicating that the regression results were robust. 
Table 3: Correlation analysis of variables

\begin{tabular}{|c|c|c|c|c|c|c|c|c|c|}
\hline & ROA & ROE & Perks & LnIC & Size & Lev & Board & Wage & Power \\
\hline ROA & 1.00 & & & & & & & & \\
\hline ROE & $\begin{array}{c}0.54 * \\
* *\end{array}$ & 1.00 & & & & & & & \\
\hline Perks & $\begin{array}{c}-0.02 \\
* * *\end{array}$ & $\begin{array}{c}-0.04 \\
* * *\end{array}$ & 1.00 & & & & & & \\
\hline LnIC & $\begin{array}{c}0.20 * \\
* *\end{array}$ & $\begin{array}{c}0.19 \\
* * *\end{array}$ & $\begin{array}{c}-0.11 \\
* * *\end{array}$ & 1.00 & & & & & \\
\hline Size & $\begin{array}{c}0.02 * \\
* *\end{array}$ & $\begin{array}{c}0.06 \\
* * *\end{array}$ & $\begin{array}{c}0.62 \\
* * *\end{array}$ & $\begin{array}{c}0.12 \\
* * *\end{array}$ & 1.00 & & & & \\
\hline Lev & $\begin{array}{c}-0.23 \\
* * *\end{array}$ & $\begin{array}{c}-0.11 \\
* * *\end{array}$ & $\begin{array}{c}0.21 \\
* * *\end{array}$ & $\begin{array}{c}-0.19 \\
* * *\end{array}$ & $\begin{array}{c}0.40 \\
* * *\end{array}$ & 1.00 & & & \\
\hline Board & $\begin{array}{c}0.03 * \\
* *\end{array}$ & $\begin{array}{c}0.03 \\
* * *\end{array}$ & $\begin{array}{c}0.16 \\
* * *\end{array}$ & $\begin{array}{c}0.03 \\
* * *\end{array}$ & $\begin{array}{c}0.25 \\
* * *\end{array}$ & $\begin{array}{c}0.15 \\
* * *\end{array}$ & 1.00 & & \\
\hline Wage & $\begin{array}{c}0.07 \\
* * *\end{array}$ & $\begin{array}{c}0.13 \\
* * *\end{array}$ & $\begin{array}{c}0.35 \\
* * *\end{array}$ & $\begin{array}{c}0.08 \\
* * *\end{array}$ & $\begin{array}{c}0.38 \\
* * *\end{array}$ & $\begin{array}{c}0.09 \\
* * *\end{array}$ & $\begin{array}{c}0.08 \\
* * *\end{array}$ & 1.00 & \\
\hline Power & -0.01 & -0.01 & $\begin{array}{c}-0.04 \\
* * *\end{array}$ & 0.01 & $\begin{array}{c}-0.15 \\
* * *\end{array}$ & $\begin{array}{c}-0.13 \\
* * *\end{array}$ & $\begin{array}{c}-0.18 \\
* * *\end{array}$ & -0.01 & 1.00 \\
\hline
\end{tabular}

Notes: $* *$ and $* * *$ indicate significance at the $5 \%$ and $1 \%$ levels, respectively.

Table 4: Regression analysis results

\begin{tabular}{|c|l|l|l|l|}
\hline & Model 1 & Model 2 & Model 3 & Model 4 \\
\hline \multirow{2}{*}{ Intercept } & $-0.2808 * * *$ & $-0.1816^{* * *}$ & -0.0165 & $0.4073 * * *$ \\
\cline { 2 - 5 } & $(-14.15)$ & $(-6.85)$ & $(-0.37)$ & $(6.90)$ \\
\hline \multirow{2}{*}{ Perks } & $-0.0018 * *$ & $-0.0029 * *$ & $-0.0198 * * *$ & $-0.0425 * * *$ \\
\cline { 2 - 5 } & $(-2.05)$ & $(-2.42)$ & $(-7.09)$ & $(-11.45)$ \\
\hline \multirow{2}{*}{ LnIC } & & & $-0.0332 * * *$ & $-0.0845 * * *$ \\
\cline { 2 - 5 } & & & $(-4.95)$ & $(-9.44)$ \\
\hline \multirow{2}{*}{ Perks_lnIC } & & & $0.0029 * * *$ & $0.0064 * * *$ \\
\cline { 2 - 5 } & & & $(6.65)$ & $(11.13)$ \\
\hline \multirow{2}{*}{ Size } & $0.0173 * * *$ & $0.0134 * * *$ & $0.0146 * * *$ & $0.0105 * * *$ \\
\cline { 2 - 5 } & $(17.18)$ & $(10.03)$ & $(14.41)$ & $(7.74)$ \\
\hline \multirow{2}{*}{ Lev } & $-0.1976 * * *$ & $-0.1276 * * *$ & $-0.1764 * * *$ & $-0.1015 * * *$ \\
\cline { 2 - 5 } & $(-44.88)$ & $(-21.7)$ & $(-38.83)$ & $(-16.76)$ \\
\hline \multirow{2}{*}{ Board } & 0.0007 & 0.0001 & 0.0007 & -0.0001 \\
\cline { 2 - 5 } & $(1.36)$ & $(0.02)$ & $(1.38)$ & $(-0.05)$ \\
\hline \multirow{2}{*}{ Wage } & $0.0001 * * *$ & $0.0001 * * *$ & $0.0001 * * *$ & $0.0001 * * *$ \\
\cline { 2 - 5 } & $(10.14)$ & $(16.04)$ & $(9.44)$ & $(15.26)$ \\
\hline \multirow{2}{*}{ Power } & $-0.0039 * *$ & -0.0012 & $-0.0038 *$ & -0.0007 \\
\cline { 2 - 5 } & $(-2.00)$ & $(-0.44)$ & $(-1.98)$ & $(-0.29)$ \\
\hline Year and Ind & Yes & Yes & Yes & Yes \\
\hline adj. ${ }^{2}$ & 0.1265 & 0.0611 & 0.1448 & 0.0842 \\
\hline N & 17824 & 17824 & 17824 & 17824 \\
\hline
\end{tabular}

Note: $*$, **, and $* * *$ denote significance at the $p<10 \%, 5 \%$, and $1 \%$ levels, respectively.

For Hypothesis 2, the internal control index was added to Hypothesis 1 as a moderator variable. The cross-term in regression (3) was positive and significantly 
correlated at the $1 \%$ level. The parameter for on-the-job consumption was -0.0198 . After adding the internal control index for the regulated variable, the parameter of the cross-item was 0.0029 . The sum of the parameters of on-the-job consumption and the cross-item was -0.0169 , which was greater than the original parameter of -0.0198 for on-the-job consumption. This indicates that good internal controls played a role in pre-prevention, supervision-in-progress, and post-supervision, and thus reduced the impact of in-service consumption on corporate performance through strict approval procedures. The regression of Model (4) supported Hypothesis -2b.

In addition, enterprise size, executive compensation, and enterprise performance were significant and positively correlated at the $1 \%$ level. This means that the larger the enterprise, the more diverse the business involved, and the higher the enterprise value created, the better the enterprise performance. Moreover, better enterprise performance was correlated with higher employee income. Financial leverage was negatively correlated with firm performance and statistically significant at the $1 \%$ level. The higher a company's asset-liability ratio, the less free cash flow the company had, which affected its profitability and reduced corporate performance.

\section{Conclusion}

\subsection{Research conclusion}

Targeting in-service consumption by executives at listed companies in China, this study examined the relationship between internal controls, in-service consumption, and corporate performance. The mediating role of internal controls in the relationship between on-the-job consumption and firm performance was also analyzed. The empirical results reveal that the higher the level of on-the-job consumption by a company's executives, the lower the company's ROA and ROE. If internal control quality was increased, the influence of in-service consumption on ROA and ROE was decreased; that is, internal controls played a major role in regulating in-service consumption and corporate performance (Wang and Jin, 2020).

\subsection{Policies and recommendation}

China has implemented internal control systems for many years, and they are part of the corporate governance structure of Chinese companies. Through empirical research results, this study proposes the following:

(1) From the government's perspective, it is necessary to establish and improve relevant laws and regulations, improve China's external supervision mechanisms for corporations, strengthen the supervision of companies listed in China, reduce the incentives for executives to engage in rent-seeking behavior, and reduce the selfinterested behavior hidden as in-service consumption.

(2) From the enterprise's perspective, attention must be paid to the construction of its internal control systems. Good internal controls reduce the damage to on-the-job consumption and -enhance enterprise performance. Enterprises must establish 
standards for evaluating the implementation of internal controls and utilize these as an incentive and supervision method. Second, enterprises should improve their corporate governance structures by separating the roles of chair and general managers into two positions. Doing so strengthens supervision and allows the board of directors to reduce the level of in-service consumption. By introducing a special system of internal controls that reasonably guides executive compensation, enterprises reduce executives' rent-seeking behavior.

\subsection{Limitations and prospects}

The study followed the method of Chen(2005), who summed up eight expense items to measure the level of in-service consumption by senior management. However, due to limitations in obtaining and disclosing data related to in-service consumption, the difficulty and errors in collecting the relevant data increased. Therefore, the data compiled utilizing this method may not accurately represent the scale of a company's in-service consumption, which lowers the quality of the relevant data.

Due to the differences in the economic and political systems of different countries and regions, future research should include factors such as regional and cultural differences in their models. Studies should also examine the impact of internal controls on in-service consumption under the influence of other factors. In this way, better theoretical guidance for company management practices could be provided.

\section{References}

Beneish, M.D., Billings, M.B., and Hodder,L.D.,(2008). Internal control weaknesses and information uncertainty. The Accounting Review, 83, 665-703.

Berle, A., and Means, G.C. (1932). The modern corporation and private property, Revised Edition.

Chen, D.H., Chen, X.Y., and Wan, H.L., (2005). Salary control and in-service consumption in state-owned enterprises. Economic Research, 2, 92-101.

Chen, H.W., and Huang, X.H., (2019). Internal control index of listed companies in China: logic, construction and verification. Audit Research, 01.

Chen, H., Hu, Y.D., and Yu, N.T. (2016). Earnings management, executive compensation-performance sensitivity and internal control governance effects. Journal of Guizhou University of Finance and Economics, 4, 45-56.

Grossman, S.J., \& Hart, O.D., (1986). The cost and benefits of ownership: A theory of vertical and lateral integration. The Journal of Political Economy, Vol.94:691-719. 
Hart, O.D., (1995). Corporate governance: some theory and implications. The Economic Journal, 105(430), 678-689.

Hart, O.D., and Moore, J. (2008). Contracts as Reference Points. The Quarterly Journal of Economics, 123(1), 1 - 48.

Hu, M.X., and Gan, S.D. (2015). Management power, internal control and executive corruption. Journal of Zhongnan University of Economics and Law, 210, 87-93.

Jensen, M.C., and Meckling, W.H. (1976). Theory of the firm: managerial behavior, agency costs and ownership structure. Journal of Financial Economics, 1, 163-231.

Jeong, S.H., and Choi, I.H. (2020). Status of manufacturing business and wavelet model. Journal of Business Models and Applications, 1(1), 19-26.

Jiang, F.X., and Huang, J.C. (2011). Managerial incentives. Liabilities and Corporate Value, 5, 46-61.

Lee, S.Y., (2020), A Reconsideration on the Leadership of Moses as the servant of the Lord. Journal of Human-centric Research in Humanities and Social Sciences, $1(1)$.

Li, Y., Qin, Y.H., and Huang, J.C., (2010). On-the-job consumption, employee wages and corporate performance. Finance. Trade and Economics, 7, 60-68

Li, Y.L., Sun J.F., and Yi, Z.H., (2012). Company heterogeneity, on-the-job consumption and institutional investor governance. Financial Research, 6, 27-37.

Liang, S., (2007). Duty consumption, black hole of recessive corruption. Journal of Party and Government Cadres, 8, 42-44

Luo, H., and Huang, W.H. (2008). Dividends of state-owned enterprises, in-service consumption and company performance. The world of Management, 9, 139-148.

Ma, D.F., and Ye, C.G., (2016). Management power, in-service consumption and company performance. Modern Management Science, 1, 94-96

Mou, S.H., Li, Q.H., and Chen, H.W., (2016). Internal control, nature of property rights and excessive on-the-job consumption. Audit Research, 4, 90-98

Ou, K.L., and Li, H., (2019). Internal control, management power and in-service consumption. Accounting Newsletter, 3, 100-103. 
Rajan, R.G., and Wulf, J., (2004). Are perks purely managerial excess? Journal of Financial Economics, 79, 1-33.

Shim S.W., and Jung L.S. (2020). A Study on the Relationship among Experience Inducing Factors, Experience Satisfaction, and Behavioral Intention: Centered on the 6th Industry. International Journal of IT-based Business Strategy Management, 6(1).

Sun, S.M., Liu, L., and Chen, Y.X. (2016). The formation mechanism of the inservice consumption economic effect and the impact of corporate governance on it. China Industrial Economy, 1, 37-51

Wan, H.L. (2007). Review of research on foreign consumption at work. Foreign Economy and Management, 29(9), 38-41.

Wang, Y.W., \&Jin, S.Y., (2020). Impact of On-the-Job consumption on corporate return on assets and equity. Journal of Business Models and Applications, 1(1), 1-6.

Xie, H.Y., Lu, Z.W., and Xie, Y.D. (2019). Party organization governance, on-thejob consumption and enterprise performance. Corporate Governance, 19, 110-115.

$\mathrm{Xu}, \mathrm{C} . \mathrm{C}$, and Yan, J.W. (2011). Research on the principal-Agent problem of stateowned enterprises. Economic aspect, 1, 92-95

Xu, X.X., and Liu, X. (2013). Decentralization reform, salary control and corporate executive corruption. The world of Management, 3, 119-132.

Zhang, B.F., and Xiu, H.X. (2017). The influence of internal control and executive power on the sensitivity of executive compensation performance. Journal of Ocean University of China, 2, 91-96 